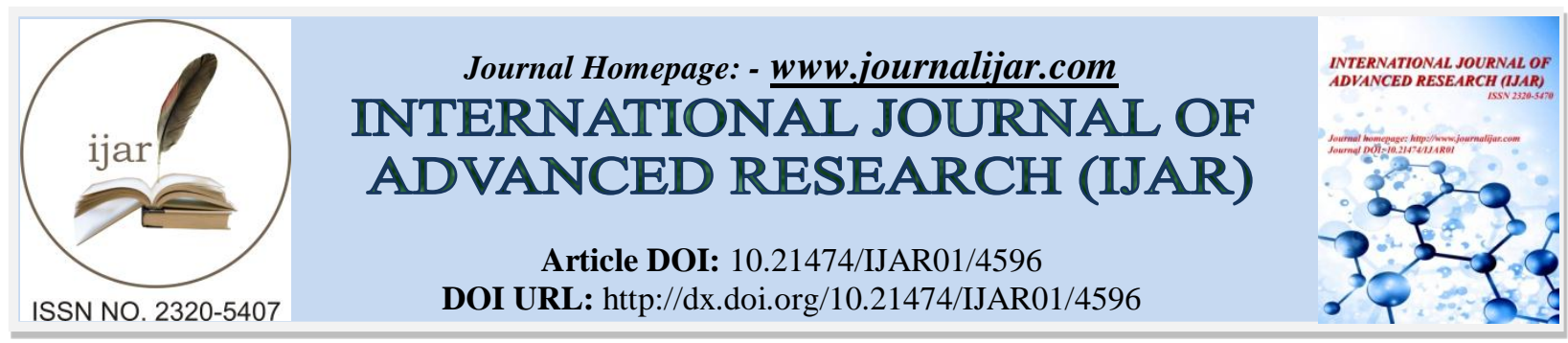

RESEARCH ARTICLE

\title{
DOMESTIC VIOLENCE AGAINST WOMEN: A BIG CHALLENGE TO THE GENDER EQUALITY IN INDIA.
}

Pratibha Pandey.

Pratibha Pandey is Research Scholar in OPJS University, Churu, Rajasthan in the subject of Home Science.

\section{Manuscript Info}

Manuscript History

Received: 24 April 2017

Final Accepted: 26 May 2017

Published: June 2017

Key words:-

Domestic Violence, Dowry, Women, Indian Society, Gender Equality, Human Rights.

\begin{abstract}
Indian women through centuries, remained subjugated and oppressed. In modern times, when women are getting education and playing role in public life, domestic violence against women has become talk of the day. It seems that men do not accept women as their equal partner. The discrimination against women can be seen in all spheres. The dowry system is the most highlighted cause of domestic violence.. The violence has become fundamental part of families. Since it is committed by family members, the women feel hesitant to inform legal agencies. The Dowry Prohibition Act, Domestic Violence Act, the UN Declaration of Human Rights and the protection of Women against Sexual harassment at Workplace Act etc. are the legal remedies through which women can fight against injustices committed against them and gradually can achieve equal status in the society.
\end{abstract}

Copy Right, IJAR, 2017,. All rights reserved.

\section{Introduction:-}

The problem of domestic violence against women in India is not new. It has been age-old phenomenon where women have been subjected to brutality. Indian women through the centuries, remained subjugated and oppressed because, the society believed in clinging on to orthodox beliefs. Women here, are discriminated against in almost all societies on the basis of gender. But in Ancient India, though the families practiced the patriarchal system, girls were looked after and educated. Women enjoyed equal status with men. Remarriage of widows was permitted and they enjoyed greater freedom. The place of honour was given to the women who participated freely alongwith their husbands in public life. During the medieval period, there was a degradation of the status of women. The daughters began to be regarded as a curse and bad luck. They did not take an inheritance. The women were denied the rights and opportunities which were granted to them in Ancient India. The dowry system, sati and purdah system downgraded women. They were largely uneducated and remained confined to the four walls of their homes. During this period, under the influence of the Muslim cultures, parents gave their daughters in marriage at a very early age. This practice gave rise to the system of child marriage which led to the lowering of the status of women. Polygamy, practiced by the upper class men, made the conditions of women quite pathetic.

Again, the status of women in India is not really promising in modern times also. The problem of domestic violence against women has become the part and parcel of their life. Domestic violence, where a woman is subjected to cruel and inhuman treatment is common in India. Women in the Indian society have been victims of humiliation, torture and exploitation. Inspite of the legislative measures adopted in favour of Indian women, and the spread of education and women's gradual economic independence, countless women still continue to be victims of violence.Patriarchy is very strong in India where woman has been treated as a commodity, a mere puppet in the hands of her so-called

Corresponding Author:- Pratibha Pandey. 
protector, be in the form of father, brother or subsequently her husband for the rest of her life. Patriarchal society has established an unequal power relationship between men and women. Patriarchy has brought with it inequality, discrimination and deprivation for women on several counts, though, in a way it was to provide security for all members in the family, including its women members. Women have also accepted subordination as part of the social ethos. Domestic violence against women stem from the fact that man cannot even today accept her as his equal partner. There is no uniform pattern of social, cultural and economic distinctions between men and women. Women today do not get the same access to health care, education, economic rights as the men of their societies do. The doors of educational, economic, social, political and cultural opportunities were gradually closed for them. Even their personal freedom in respect of movement, diet, dress etc. came to be curtailed. Women have become sex objects for men and are widely treated as inferior to men in different spheres of life. Now, girls are perceived as a burden on the family, because huge amounts of money are required for their weddings.

There is also huge discrimination between men and women in the sphere of education and the reason attributed to such gender bias is the feeling of the people that girls should be confined to the house. Boys, on the other hand, are educated because they are destined to provide for their family and support the parents in their old age.

Again, the women in India are discriminated on the basis of gender in participating the decision making process of their own country. They are not getting equal status and position in politics like their male representatives. Though their status in social, economic and political fields in India today is much higher than in ancient and medieval periods and women today enjoy many more rights having greater freedom and voice, but it is true that they are still discriminated, harassed and exploited.

Further, the women in India are generally tied up with household responsibilities which leave them very little time to attend meetings. Many are not allowed by their husbands and in most of the cases, it is the husband who makes the decisions for panchayat and the wives put their signatures or thumb impressions on the official documents. Women representatives in the local bodies have not been treated with the dignity they deserve. In many times, they face indifference from their male colleagues in the meetings and felt hurt for not having been heard or supported and even if they presented relevant arguments. Similarly, the male party leaders compete with each other in announcing their support for 33 percent reservation for women in parliament and state legislatures. These politicians have shown little willingness to include women in party decisions, or to help create a conductive atmosphere for women's participation in their own organizations. Most women in electoral and party politics are an ineffective minority within their own respective political groupings. Though the country is witnessed the appointment of a woman as its prime minister and various states in India have from time to time, had women chief ministers and women Governors and also by electing now a woman as its president, still women have not really made any remarkable inroads into politics.

Domestic violence against women is now a big threat to the gender equality in India. It has assumed an alarming proportion. Domestic violence takes a dismaying variety of forms, such as, domestic abuse, dowry deaths, wife beating, sexual harassment etc. which are reported in newspapers and other Indian media very frequently. Recently, violence has become a fundamental part of family life. The stressful situations in the family give rise to maladjustment, and this in turn results in violent behaviour. Even, murders in the family may often be due to severe family stress and crisis, inter-spouse relationships are many a time unstable. The wives then face serious adjustment problems with their in-laws and spouses. Some husbands drink and gamble, squandering money that must go to maintain the family.

The prevalence of dowry system in Indian society, at present, has taken a vicious shape, and is a serious crime against women. The evils of dowry cause havoc in the lives of parents and the young girls. The parents of the girl hope that she should not face any difficulty in managing her new family and therefore, they send her to her new home with a pile of gifts. But over the years, the custom of dowry has degenerated and marriage now has become like a business transaction. It is now accepted as a form of marriage payment made by the parents of the women to the couple on marriage. As the time progressed, human greed turned it into something that was to be demanded as a right in accordance with the social standing of the groom and his family. In most of the cases, it has been noticed that the mother-in-law of the young bride often raises a hue and cry against the inadequacy of the dowry brought into the family. She at times is known to instigate her son and relatives to resort to harassing the young bride and sometimes such incident take a gruesome shape and ends either in suicide of the bride or her death at the hands of her in-laws and their relatives. 
Though the Dowry prohibition Act was passed in 1961 which was modified to the Dowry prohibition Act of 1984 and was further amended in 1986 to provide it more strength to curb this anti-social practice and made dowry offences non-bailable, the practice had such deep social roots that nothing much could be done. Besides, the Indian penal code also punishes the bride burning, cruelty and torture to brides. The Indian Evidence Act also provides that accused has to bear the burden of proof. In spite of laws, this ugly system is still prevailing in our country. Every day, the newspapers publish horrifying news about bride-burning, bride's suicide, bride's murder etc. which is a great shame for our society.

Wife beating is another form of domestic violence and atrocity against Indian women. A husband, who is supposed to love and protect his wife, beats her mercilessly. Domestic violence can range from slap and kicks to broken bones, torture and attempted murder and even murder itself. on December 14, 2010, the citizens of Dehradoon woke up to the news of the grisly murder of 33 year old Anupama Gulati by her husband and software engineer Rajesh Gulati. He allegedly murdered his wife, cut the body into 72 pieces with the help of a stone cutter after she was strangled on October 17 and hid it in a deep freezer for nearly two months. The police said it would investigate the case under "rare of the rarest cases." This incident has again put a question mark on the safety of woman within the family.

Similarly, sexual harassment in the workplace is a growing concern for Indian women. It is the most shocking crimes against human conscience and morality and is the most serious offence against the dignity and modesty of women. In recent years, there is an increasing number of women who are working outside the family to get income for the family. But it is shame that these women are harassed in offices, public places, during travel etc. unfortunately, nobody bothers to think about the condition of women at workplace. The women suffer all humiliation in silence and take it as their destiny. Girls also develop a feeling of insecurity in their homes when they are sexually exploited.They lose their self-confidence and desire for living. They become completely depressed and in many times lost their lives.It has been laid down by the Supreme Court that it is the duty of the employer or other responsible persons in work places or other institutions to prevent or deter the commission of acts of sexual harassment and to provide the procedure for the resolution, settlement or prosecution of acts of sexual harassment by taking all steps required. Sexual harassment of women in offices, establishments, educational institutions etc. led to the famous case of Vishaka v. State of Rajasthan, wherein the supreme court held that sexual harassment of working women at their places of work amounts to violation of the fundamental rights guaranteed by Articles 14, 15 and 23 of the constitution. One of the most shocking news which almost all the newspapers of the country published on 11 February, 2008, that several boys and girls, in the age group of 7-10 years, residing in an orphanage named 'Nabarun Home' at Hariharpur in Baruipur south 24 parganas, west Bengal, run by a French sponsored NGO, were allegedly sexually harassed for months by the caretakers of the home. This news greatly shocked all sections of people in the society and shook the entire country. It seems that the mechanism to prevent and control such heinous crime is not functioning properly and still the crime is growing day by day.

Domestic violence, really, is the most pernicious and most insidious form of violence which Indian women suffer in silence because of the social norms and also because of her economic dependence on the perpetrators of the violence.Thefindings released in Washington, reiterated that although India may be on its way to becoming the world's fastest developing economy, it figures at the bottom of the pile when it comes to gender equality. The Director of International centre for Research on women (ICRW)'s Asia regional office in Delhi, Ravi Verma said that Indian men are far more traditional, to put it mildly. Even young, educated men are not changing as rapidly as women. They are still living in the old ages". Preventing violence against women globally is a long standing area of work for ICRW. In India, the organization since the early 1990 has been playing a pivotal role in gender-based abuse prevention research and policy making.

Gender equality in India would be a distant dream if domestic violence against women is not minimized. No process of development can be considered complete where women continue to remain subjugated. The Greek political philosopher, Plato, wanted that the talents of the women should be utilized for the benefit of the society. He therefore, wanted that women should be accorded due and legitimate position in the society. He saw no difference of kind between man and woman except in case of sex.

From the very beginning, the UN has taken numerous steps to ensure legal equality for women and set up a commission on status of women in 1946 to protect the interests of women. In 1948, the universal Declaration of Human Rights also asserted that women were entitled to all rights enshrined in the Declaration at par with men. The 
most important step in the direction of improving the condition of women was taken in 1979 when the UN General Assembly adopted convention on the elimination of all forms of discriminations against women. The convention emphasized the importance of education of both men and women to bring about a change in their attitudes so that the prevailing prejudices and practices based on old traditions can be overcome. Different feminist movements urge that women's situation and the inequalities between men and women should be treated as central political issues. All streams of feminist thought focus in the causes and remedies of women's inequality, subordinate or oppression.

Our Government is also committed to provide protection to women against domestic violence by enacting Domestic Violence Act, 2005, which came into force on 26th October, 2006 to provide for more effective protection of the rights of women guaranteed under the constitution. Any woman who is or has been in a domestic or family relationship if is subjected to any act of domestic violence, can complain under the act to the protection officer and the appeal can be made to session's court within 30 days from the order of concerned Magistrate. The protection of women from Domestic violence Act (PWDVA) is also implemented by the states /Union Territories. The state Governments are required to appoint protection officers, Register Service providers and notify shelter homes and medical facilities for implementation of the Act. The PWDVA is a civil Law meant to protect and provide support to victims of domestic violence. Under the Act, the aggrieved woman can seek various reliefs, such as, protection order, residence order, custody order, compensation order, monetary reliefs, shelter and medical facilities. The Act also has a provision for appeal against the orders of the Magistrate.Another good news for the women in India that the government of Andhra Pradesh intends to have separate 'Mahila Court' attached to the courts complex in every district which is to take atrocities on women more humanely dealt. These Mahila Courts will necessarily apply police to cooperate with the general public at large and voluntary agencies to sensitize the issues and vulnerabilities related to women. Being disturbed at the increasing use of acid attack on women, government wants to impose stringent punishment for offenders at par with murder.

Also, the Union Cabinet approved the introduction of the protection of women against sexual Harassment at workplace Bill, 2010, in the parliament to ensure a safe environment for women at work places, both in public and private sectors whether organized or unorganized. The Bill provide protection not only to women who are employed, but also to any woman who enters the workplace as a client, customer, apprentice and daily wage worker or in ad-hoc capacity.20 The measure, thus, will help in achieving gender empowerment and equality in India.

Despite of these legislative measures adopted by the Government of India as well as state Governments in favour of women, countless women of the country still continue to be victims of domestic violence. Some practical steps should be taken to put a check on domestic violence against women which has terrible effects on the family and society. Women must organize themselves against a system that turns a blind eye towards violent acts against women. The role of Non-Governmental organizations (NGOS) in controlling the domestic violence and curbing its worse consequences is crucial. Police should play major role in tackling the domestic violence cases. There should be a separate wing of police dealing with women's issues, attached to all police stations. The media should also play a vital role in making people aware of the domestic violence rules. Each and every citizen of the country needs a social awakening by which their attitudes towards women will be changed. Government should set up special fasttrack courts which could deal with all types of domestic problems of women. We hope that, in the future, the domestic violence against women would be reduced greatly.

\section{References:-}

1. Ram Ahuja.2010. Social problems in India. Rawat Publishers, New Delhi.

2. Nadeem Hasnain.2006. Indian society and culture: Continuity and Change. Jawahar Publishers, New Delhi.

3. Ram Ahuja.2010. Society in India: Concepts, Theories and Recent Trends. Rawat Publishers, New Delhi.

4. Roopashri Sinha, Asha Singh and Piyush Bajpai, "Women's Participation in Panchayati Raj for Improving Health Status", The Journal of Family Welfare, vol. 48, special issue, 2002.

5. Y. Ashok Kumar”, Dynamics of Intra-Family violence-Need for Intervention”, Social Welfare, vol. 55, No. 3, June, 2014

6. Ahuja,B.2011.Domestic Violence.Mittal Publications,New Delhi.Ibid,

7. Ram Ahuja.2009. "Social problems in India", Rawat publishers, New Delhi.

8. The Pioneer, December 14, 2010.

9. J.L. Kachroo \& Vijay Kachroo.2010. Society in India. Cosmos Bookhive Publishers, Gurgaon.

10. Ankur Kumar, Domestic Violence in India: Causes, Consequences and Remedies, http://www.youthkiawaaz.com. 
11. Arkodeb Sinha, "Sexual Harassment At workplace - An overview", Legal service India.com

12. Manish Arora.2010. Short Esays on Law. Universal Law publishers, New Delhi.

13. "Synopsis of Parliament Debate on the protection of women from Domestic Violence Bill, 2005", http:// www. pariwriksuraksha.org/ debatedv.htm.

14. Neha Bhayana, "Indian men lead in sexual violence, worst on Gender Equality: study", http://articles.timesofindia.indiatimes.com

15. Prakash Chander.2011. Comparative Politics and International Relations", Cosmos Bookhive Publishers, Gurgaon..

16. O.P. Gauba.2003. 'Diverse perspectives on justice', in O.P. Gauba's An Introduction to Political Theory. Macmillan Publishers, Delhi.

17. Manish Arora.2010. Short Essays on Law. Universal Law publishers New Delhi.

18. News Panorama, vol. 23, No. 03, January, 2011, p. 13.

19. Panorama year Book, 2010, vil. 1, p. 96.

20. Mahendra's Current Affairs, January, 2011, p. 32. 